О.В. КАБАЦЬКА

\title{
ВИВЧЕННЯ ПІДХОДІВ ДО РОБОТИ ВИКЛАДАЧІВ ЗАКЛАДУ ВИЩОЇ ОСВІТИ В НАПРЯМУ ЗДОРОВ'ЯЗБЕРЕЖЕННЯ СТУДЕНТІВ
}

\author{
(C) Кабацька О.В., 2020 \\ https://orcid.org/0000-0001-7984-7391 \\ http://doi.org/10.34142/2312-2471.2020.63.07
}

Актуальність проведеної роботи підкреслюється активізацією уваги до здоров'я студентів в процесі освіти, цее пов'язано із зацікавленістю суспільства у самореалізації фахівців у професійній діяльності, занепокоєнням зростанням їх захворюваності в проиесі професійної діяльності з наступним зниженням працездатності. 3 метою вивчення сучасного стану забезпечення освіти в напряму здоров'язбереження студентів в закладі вищої освіти було проведено дослідження, яке здійснювалося за допомогою анкетування, спостереження та бесіди. В дослідженні приймали участь викладачі та студенти Харківського національного педагогічного університету імені Г. С. Сковороди. У результаті проведеної роботи з'ясовано, щуо молоді педагоги недостатньо використовують психолого-педагогічні знання щзодо вікових та індивідуальних закономірностей розвитку особистості 8 студентському віці, в малому обсязі застосовують здоров'язбережувальні технології в прочесі викладання. Спостереження за стилями педагогічної взасмодії досвідчених педагогів зі студентами засвідчило, щуо в цілому досвідчені педагоги грамотно структурують свою педагогічну діяльність. Наприклад, педагоги (переважно з педагогічним стажем 15 б більше років) активно взаємодіють зі студентами, застосовують у своїй професійній діяльності ефективні форми педагогічного спілкування. Також виявлено, шуо при проведення практичних занять педагоги залучають різні форми та методи активізації діяльності студентів, щзо забезпечує поглиблення та закріплення знань, отриманих в прочесі викладання. Водночас, педагоги не готові до перебудови стереотипу як викладання, так $і$ взаємин зі студентами. До того ж, педагоги мають низьку мотивацію зі збереження власного здоров'я $в$ умовах професійної діяльності. Під час індивідуальної бесіди педагоги зазначили, щзо в освітньому процеесі використовують традиційні методи й прийоми навчання, не приділяючи особливої уваги специифічним здоров'язбережувальним освітнім технологіям. Педагоги підкреслили, щуо важливим аспектом забезпечення здоров'язбережувальної діяльності $\epsilon$ створення сприятливої навчальної атмосфери. Саме тому на лекиійних та практичних заняттях педагоги використовують прийоми інтелектуальноемоційного стимулювання студентів, які створюють комфортне середовище, 
позбавлене страхів та стресів. У результаті проведеної роботи з'ясовано, щуо переважна більшість студентів взагалі не усвідомлюють свою роль у здоров'язбережувальному освітньому прочесі, хоча всі (100\%) відзначають ї̈ важливість. Майже всі студенти (95\%), як і викладачі, мають не високу мотивацію до збереження власного здоров'я, вважаючи, щзо займатися здоров'ям їм заважає матеріальний стан, нестача часу для вживання оздоровчих заходів, відсутність мотивачії. Значна кількість студентів (81,6\%) зазначили, щзо педагогам перешкоджає проводити роботу для збереження здоров'я студентів відсутність у закладі умов для проведення ичієї роботи, відсутність стимулювання з боку адміністрації закладу, відсутність мотивації та недостатній рівень знань для використання здоров'язбережувальних технологій в освітньому проиесі.

Ключові слова: викладачі, студенти, заклад вищуӧ освіти, здоров'язбереження.

\section{Kabatska O. V. Study of Approaches to Teachers' Work in Higher Education Institutions in the Direction of Students' Health Protection}

The work urgency is emphasized by the attention intensification to students' health in education, this is due to public concern about the self-realization of professionals in higher education, the growth of morbidity in training, followed by reduced efficiency. In order to study the current state of education in the field of students' health in higher education, the study was conducted, that was carried out through questionnaires, observations and interviews. Teachers and students in H. S.Skovoroda Kharkiv National Pedagogical University took part in this research. As a result of this work, it was found out that young teachers do not make sufficient use of psychological and pedagogical knowledge about the age and individual patterns of stunebts' personality development, use health technologies in the teaching process little. The styles observation in teachers' pedagogical interaction with students showed that experienced teachers structure their pedagogical activities in general quite competently. For example, teachers (mostly with teaching experience of 15 years or more) interact actively with students, use effective forms of pedagogical communication in their professional activities. It was also found out that during practical classes teachers involve various forms and methods of students' activities intensification that provides deepening and consolidation of the knowledge gained in the teaching process. At the same time, teachers are not ready to restructure the stereotype of both teaching and relationships with students. In addition, educators have low motivation to take care of their own health in the context of professional activities. During the individual conversation, the teachers noted that they use traditional teaching methods and techniques in the educational process, without paying much attention to specific health-preserving educational technologies. Educators stressed that an important aspect of health care is to create a favorable learning atmosphere. That is why teachers use methods of intellectual and emotional 
stimulation for students in lectures and practical classes, it creates a comfortable environment free from fears and stress. As a result of this work, it was found out that the vast majority of students are not aware of their role in the health education process, although all (100\%) note the importance of such a role. Almost all students (95\%), as well as teachers, have a very low motivation to take care of their own health, believing that their health is hindered by financial situation, lack of time to take health procedures, motivation lack. A significant number of students (81.6\%) say that teachers are hampered by the lack of conditions in the institution for the students' work, lack of incentives from the institution administration, motivation lack and insufficient knowledge for the use of health technologies in the educational process.

Keywords: teachers, students, higher education institution, health care.

Постановка проблеми. В нашій країні, яка стрімко змінюється та розвивається, спрямовуючи освітні програми на сучасні вимоги до фахівців різноманітних профілів та сфер життя людини, необхідний новий погляд на здоров'я молодого покоління. Сьогодення в освіті студентів сфокусована увага на здоров'я, це пов'язано із зацікавленістю суспільства 3 приводу реалізації потенціалу фахівців та збереження їх життєвого ресурсу на багато років. Майбутні фахівці, що випускаються вищою школою, мають захворювання, які набути в процесі професійної підготовки, 3 наступним зниженням їх працездатності. Необхідні зміни в мисленні та способі життя молодого покоління сучасної України.

Аналіз останніх досліджень і публікацій. Здоров'я як наукову проблему розглядали різні вчені. Важливість валеологічної освіти та виховання підкреслювали: В. Бабич, Ю. Бойчук, І. Брехман, М. Гончаренко, В. Горащук, В. Грибан, В. Казначеєв, I. Муравов, С. Омельченко, В. Петленко, Н. Побірченко та інші. Здоров'я в освітньому процесі як медичну проблему розглядали: Г. Апанасенко, Т. Бойченко, Л. Попова, Г. Топоров та інші. Професійна підготовка педагогів, які будуть зберігати здоров'я учнів та студентів, розкрита в наукових працях: Т. Бойченка, М. Гриньової, О. Міхеєнка, В. Оржеховської, I. Поташнюка, А. Царенка та інших.

Сучасними вченими Г. Апанасенком, Л. Сущенко, Л. Поповою та іншими науковцями класифіковано педагогічні технології, які спрямовані на здоров'язбереження в процесі освіти, - з безпеки життєдіяльності людини; медико-гігієнічні; екологічні; фізкультурно-оздоровчі та інші.

Зміцнення здоров'я студентів вивчали й зарубіжні вчені, які дослідили, що «рівень здоров'я залежить від соціального статусу». Вони наголошують на необхідності інтеграції здоров'язбережувальних дисциплін в освітні програми всіх університетів [8, с. 5].

Наприклад, такий напрямок наукових досліджень, як «родинна оздоровча історія» розкрито у працях Ronica N. Rooks та Cassandra D. Ford. Впровадження такого напряму в освіті забезпечує студентам запобігання загострення 
хронічних захворювань тому, що вони володіють важливою інформацією про генетичні хвороби в їх родинах та уявляють важливість родини, як моделі, яка вливає на здоров’я та формує основні життєві навички [6, с. 328].

Вчена А. Бєсєдіна в своїх наукових працях розкриває поняття «здоров' язбережувальна або здоров'яспрямована діяльність» - «спрямована на формування, збереження та зміцнення здоров’я дітей, підлітків та молоді...». Вона спирається на думку О. Сжової, що діяльність, яка забезпечує збереження здоров'я - «здоров'язбережувальна»; яка зміцнює здоров'я «здоров'язміцнювальна»; діяльність, яка забезпечує формування здоров'я «здоров'яформувальна». Всі види діяльності взаємопов'язані в процесі педагогічного впливу на учнів та студентів [1, с. 47].

Також А. Бєсєдіна, спираючись на наукову позицію О. Сжової, розкриває розуміння «здоров’яспрямованої діяльності», як «сукупності планомірних освітніх дій та заходів, зосереджених на збереженні та зміцненні здоров'я дітей, підлітків і молоді шляхом сприяння формуванню в них ціннісного ставлення до власного здоров'я та здоров'я інших...». Таке тлумачення показує діяльність, яка «не зашкоджує здоров’ю суб'єктів освітнього процесу, а має здоров'язбережувальний, здоров'язміцнювальний та здоров'яформуючий вПлив» $[1$, с. 54].

А. Бєсєдіна проаналізувала різні тлумачення «здоров’яспрямованої діяльності». Наприклад, тлумачення J. Karski (Польща): пропаганда здорового способу життя «охоплює всі чинники, що сприяють підвищенню якості здоров’я» [4, с. 22]; тлумачення Н. Štumarová (Чехія): «діяльність, спрямована на визначення, розуміння i усвідомлення основних прав кожної людини на здоровий розвиток, охорону здоров'я у такий спосіб, щоб не ставити під загрозу здоров'я інших» [7, с. 14]; дослідники В. Paksi, K. Felvinczi, A. Schmidt (Угорщина): «здоров’яспрямована діяльність, планомірна на здійснення заходів щодо зміцнення здоров'я; система заходів передбачає надання необхідної інформації про формування, збереження і зміцнення здоров'я, піклування та контроль за власним здоров'ям» [5, с. 4]; А. Маджуги (Росія): «передбачає формування у суб'єктів освітнього процесу досвіду та мотивації щодо активного пошуку оптимальних стратегій, спрямованих на актуалізацію свого здоров'я» [3, с. 11].

Виділення невирішених раніше частин загальної проблеми. Ведення здорового способу життя як власної форми життєдіяльності молодої людини розкриває нові можливості самореалізації та збереження ресурсу організму на довгі роки, що сприятиме високої працездатності фахівців будь якою сфери життя в суспільстві.

В університетах студенти навчаються використанню здоров'язбережувальних освітніх технологій в професійній діяльності. Також майбутні педагоги, вивчаючі особливості впровадження в освітніх закладах валеологічних підходів при проходженні виховної та педагогічної практик, допомагаючи школярам «сформувати базові навички з основ здоров’я», набути 
знання для ведення здорового способу життя та формування в них здорової поведінки [2, с.192].

Цікавим було виявити особливості використання здоров’язбережувальних освітніх технологій викладачами та студентами на факультетах закладів вищої педагогічної освіти, які не мають здоров'язбережувальної спрямованості.

Мета та завдання дослідження. Метою дослідження було виявлення сучасного стану забезпечення студентів здоров'язбережувальною освітою. Завданнями дослідження було: з'ясувати сутність понять «здоров’ язбереження» та «здоров’ яспрямована діяльність»; виявити готовність студентів та викладачів до використання здоров'язбережувальних педагогічних технологій в закладі вищої педагогічної освіти.

Методи дослідження. Дослідження здійснювалося за допомогою анкетування, спостереження та бесіди. В дослідженні приймали участь викладачі та студенти Харківського національного педагогічного університету імені Г. С. Сковороди.

Виклад основного матеріалу. Важливим у роботі педагогів 3 молодим поколінням є оволодіння інноваційними методами навчання, орієнтованими на імпровізацію, науковий пошук, творчість, підтримку евристичної діяльності, витіснення авторитарних методів в освіті. Використання таких методів забезпечує також й здоров'язбережувальну діяльність, показує студентам як правильно діяти, зростати творчими особистостями, виробити власну установку на підтримку здоров'я. Засобами в здоров'язбережувальної спрямованості освіти є використання комплексних проблемних питань та завдань, створення евристичних ситуацій та проблемних ситуацій валеологічного змісту, виконання вправ для відпрацювання комплексних дій, проведення тестів та анкетування, оновлення навчальних посібників та хрестоматій, розглядання та аналіз творів мистецтва тощо.

Проаналізувавши результати проведеного нами дослідження виявлено, що при проведення практичних занять педагоги використовують різні форми активізації діяльності студентів, які забезпечують поглиблення знань, вмінь та навичок отриманих на заняттях, а саме: «круглі столи»; диспути за темами «Чи є обов’язком педагога здоровий розвиток студента?», «У чому для мене особисто полягають цінності педагогічної праці?» тощо. Такі форми педагогічної роботи сприяли розвитку професійно-педагогічної спрямованості, забезпечували усвідомлення студентами значущості здійснення здоров’язбереження. Рольові та ділові ігри, аналіз різних педагогічних ситуацій в професійної діяльності, спрямовано на самостійний пошук оптимальних рішень та поведінки тощо.

Обговорення. За результатами дослідження з'ясовано, що переважна більшість студентів взагалі не усвідомлюють свою роль у здоров’язбережувальному освітньому процесі, хоча всі (100\%) відзначають важливість роботи в цьому напрямку. 
Велика кількість студентів (95\%), як і респонденти-викладачі, мають досить низьку мотивацію до збереження власного здоров'я, вважаючи, що займатися здоров'ям їм заважає матеріальний стан, нестача часу для вживання оздоровчих заходів, відсутність мотивації.

$81,6 \%$ студентів зазначили, що педагогам перешкоджає проводити роботу для збереження здоров'я майбутніх фахівців відсутність у закладі умов для проведення такої роботи, відсутність інтересу та стимулювання з боку адміністрації закладу, відсутність мотивації та недостатній рівень знань для використання здоров' язбережувальних технологій в освітньому процесі.

За результатами анкетування педагоги зазначили, що в освітньому процесі важливе місце посідають екскурсії та заняття психологічного розвантаження. Екскурсії підвищують працездатність студентів, активізують їх пізнавальні інтереси, здійснюють сприятливий вплив на фізичне та психічне здоров'я.

Також за результатами дослідження виявлено, що педагоги вважають важливим аспектом забезпечення здоров'язбережувальної діяльності створення сприятливої навчальної атмосфери.

За нашими спостереженнями, психолого-емоційна атмосфера, ті взаємини, що встановлювалися під час проведення занять психологічного розвантаження, мали стійку післядію й позитивно впливали й на інші навчальні заняття. Зокрема, після цих занять студенти були більш активними, уважними, ефективніше виконували навчальні завдання.

Цікавими були уявлення студентів про сутність та зміст здоров'язбережувальної діяльності педагога у закладі вищої освіти. Були отримані такі відповіді:

- уміння висувати перед студентами мету збереження здоров'я людини та мотивувати студентів на досягнення цієї мети;

- здатність педагога розв'язувати педагогічні ситуації без шкоди для здоров'я особистості;

- уміння застосовувати свої знання, вміння та навички здоров'збереження в різних життєвих ситуаціях;

- використання форм та засобів освіти, спрямованих на збереження здоров'я студентів;

- знання новітніх здоров'язберігаючих підходів, уміння їх застосовувати;

- високий рівень професійної педагогічної кваліфікації, здатність спрямувати свої дії на збереження та відновлення здоров'я особистості через освіту;

- надання професійних консультацій та рекомендацій для ведення здорового способу життя;

- проведення профілактичних заходів в напряму здоров'язбереження;

- наявність комплексу знань, умінь, навичок в педагога та його особистий приклад здоров'язбережувальної діяльності. 
Під час дослідження студентам було запропоновано назвати форми та методи здоров'язбережувальної діяльності педагога. 53,3 \% студентів не змогли виделіти конкретні форми, методи, засоби організації такої діяльності. Але, серед відповідей були перелічені різні форми та методи активізації навчальнопізнавальної діяльності, що забезпечують поглиблення та закріплення знань, отриманих у ході занять, а саме: «круглі столи»; диспути; лекції; виховні години; соціально-психологічні тренінги; перегляд фільмів; проведення екскурсій до закладів, де можна спостерігати приклади, коли людина не дбає про своє здоров'я тощо.

Значний відсоток студентів (85\%) зазначили, що принциповим моментом діяльності педагога $\epsilon$ інтелектуально-емоційна підтримка студентів та проведення фізкультурних хвилинок та розминок, гімнастики очей, музикотерапії.

Майже всі студенти зазначили, що педагог у своїй діяльності повинен обов'язково застосовувати такі оздоровчі технології, які спрямовані на зміцнення фізичного здоров'я студентів, підвищення ресурсів здоров'я.

За результатами дослідження педагогами була запропонована така тематика занять:

- здоров'я людини, як найвища цінність, сутність категорій «здоров'я», «здоровий спосіб життя», «безпека життєдіяльності», «культура здоров'я особистості»;

- фактори негативного впливу на здоров'я в процесі освіти;

- погляди видатних педагогів на збереження й зміцнення здоров'я людини;

- вплив особистостого прикладу педагога на здоров'я студентів тощо.

Висновки. Узагальнюючи результати проведеного дослідження, можна дійти висновку, що більшість респондентів розуміють необхідність використання педагогами здоров'язбережувальних технологій в процесі освіти студентів. Однак, вони не мають відповідних знань щодо впровадження таких технологій. Майже половина студентів не замислюється про необхідність свідомого ставлення до здоров'язбереження, не цікавиться цими питаннями.

Для здоров'язбереження студентів в закладі вищої освіти необхідне виконання таких умов, а саме: впровадження системи методичної роботи 3 педагогами, спрямованої на підвищення їх кваліфікації в напряму збереження й зміцнення здоров'я людини; координація зусиль всіх, хто забезпечує навчання та виховання молоді у закладі 3 питань гігієнічних умов та впровадження здоров'язбережувальних технологій впродовж всієї освіти; забезпечення науково-методичної та матеріальної бази для озброєння знаннями, вміннями та навичками $з$ основ здоров'я студентів та викладачів; взаємодія співробітників закладу та студентів, орієнтована на захист і підтримку здоров'я; використання викладачами на заняттях та в позааудиторної роботі інноваційних технологій збереження здоров'я; впровадження нових педагогічних технологій безпосередньо під час лекційних, семінарських та практичних занять; 
розроблення освітніх програм дисциплін 3 доповненням темами 3 основ здоров’я людини тощо.

Перспективи подальших розвідок. Вивчаючи особливості впровадження здоров'язбережувальних технологій в освіту студентів, можна порівняти результати відповідей майбутніх педагогів класичних та педагогічних університетів та додати до результатів дослідження аналіз навчальних планів, які забезпечують професійну підготовку фахівців.

\section{Лimepamypa}

1. Сжова О.О. Формування ціннісного ставлення до здоров'я в учнів професійно-технічних навчальних закладів : монографія. Суми: МакДен, 2011. $412 \mathrm{c}$.

2. Кабацька О.В., Поколодна І.О. Дослідження особливостей оцінювання здоров'язбережувальних знань учнів майбутніми педагогами. Педагогіка формування творчої особистості у вищій $i$ загальноосвітній школах : зб. наук. пр. / гол. ред. T.I. Сущенко. Запоріжжя, 2017. Вип. 55 (108). С. 187-194.

3. Маджуга А.Г. Педагогическая концепція здоровьесозидающей функции образования : автореф. дис. ... д-ра пед. наук : спец. 13.00.01 «Общая педагогика, история педагогики и образования». Владимир : ВлГУ, 2011. 49 с.

4. Karski J.B. Praktyka i teoria promocjiz drowia. Warszawa:Wyd-wo «eDeWu », 2003. $296 \mathrm{~s}$.

5. Paksi B. Prevenciós / egészségfejlesztési tevékenység a közoktatásban, A közoktatási intézményekben alkalmazott prevenciós [Electronic resource] / B. Paksi, K. Felvinczi, A. Schmidt. Kutatási, 2004. URL: http://www.nefmi.gov.hu/2005/prevencios-tevekenyseg.

6. Rooks R.N., Ford C.D. Family Health History and Behavioral Change among Undergraduate Students: A Mixed Methods Study. Health. 2016. Vol. 8. P. 325-335. URL: doi: 10.4236/health.2016.84034.

7. Štumarová $H$. Výchovakezdravína ZŠ a rodina: diplomovápráce. Brno: Masarykovauniverzita, 2007. $140 \mathrm{~s}$.

8. Factors affecting health-promoting behaviors of university students in Jordan / A. Shaheen, O. Nassar, H. Amre [et al.]. Health. 2015. Vol. 7. P. 1-8. URL: doi : 10.4236/health.2015.71001.

\section{References}

1. Jezhova, O.O. (2011). Formuvannja cinnisnogho stavlennja do zdorov'ja v uchniv profesijno-tekhnichnykh navchaljnykh zakladiv [Formation of a valueattitude to health in students of vocational schools]. Sumy : MakDen (in Ukrainian).

2. Kabatska, O.V., \& Pokolodna, I.O. (2017). Doslidzhennia osoblyvostei otsiniuvannia zdoroviazberezhuvalnykh znan uchniv maibutnimy pedahohamyvaleolohamy [Research on the features of assessing students' health-saving knowledge by future educators-valeologists]. Pedahohika formuvannia tvorchoi osobystosti $u$ vyshchii i zahalnoosvitni ishkolakh - Pedagogy of formation of creative 
personality in higher and secondary schools. T. I. Sushchenko (Ed). (Vol. 55(108), (pp. 187-194). Zaporizhzhia (in Ukrainian).

3. Madzhuga, A.G. (2011). Pedagogicheskaja koncepcija zdorov'esozedajushhej funkcii obrazovanija [Pedagogical concept of health creative function of education]. Extended abstract of Doctor's thesis. Vladimir: VlGU (in Russian).

4. Karski, J. B. (2003). Praktyka i teoria promocji zdrowia. Warszawa: $\mathrm{CeDeWu}$ (in Poland).

5. Paksi, B., Felvinczi, $\quad$ K., $\quad \&$ Schmidt A. (2004). Prevenciós egészségfejlesztési tevékenység a közoktatásban, A közoktatási intézményekben alkalmazott prevenciós. Retrieved from http://www.nefmi.gov.hu/2005/prevenciostevekenyseg (in Hungarian).

6. Rooks, R., \& Ford, C. (2016). Family Health History and Behavioral Change among Undergraduate Students: A Mixed Methods Study. Health, 8, 325-335. Retrieved from doi: 10.4236/health.2016.84034 (in English).

7. Štumarová, H. (2007). Výchovakezdravína ZŠ a rodina: diplomovápráce. Brno: Masarykovauniverzita (in Czech).

8. Shaheen, A., Nassar, O., Amre, H. \& Hamdan-Mansour, A. (2015). Factors Affecting Health-Promoting Behaviors of University Students in Jordan. Health, 7, 1-8. Retrieved from doi: 10.4236/health.2015.71001 (in English). 